\title{
Study of Gasohol as Alternative Fuel for Gasoline Substitution: Characteristics and Performances
}

\author{
Bardi Murachmana*, Dicky Pranantyo ${ }^{a}$, Eddie Sandjaya Putra ${ }^{a}$ \\ a Laboratory of Petroleum, Gas and Coal, Department of Chemical Engineering, Faculty of Engineering, \\ Gadjah Mada University, Yogyakarta, Indonesia
}

\begin{abstract}
Gasohol is a mixture of premium petrol (gasoline) with alcohol, in this case ethanol. The use of gasohol can reduce fuel consumption without having to modify the existing engine. Therefore, this research is conducted to study the characteristics and performance of gasohol in various mixing ratios, which includes analysis of physical properties and the use of gasohol in the machine. Results show that the addition of technical ethanol at $7.0169 \% \mathrm{v}$ increases the value of gasohol vapor pressure on the value of $8.6682 \mathrm{psi}$ (7.7 psi for regular gasoline). Gasohol with technical ethanol content above $30 \% \mathrm{v}$ decreases vapor pressure, promotes phase separation, and causes a sharp drop in temperature from $40 \% \mathrm{v}$ distillation. In term of corrosivity, gasohol with up to $50 \% \mathrm{v}$ ethanol content has the same corrosion level with regular gasoline, which is corrosion level $1 \mathrm{~A}$. Based on gasohol characteristics test, it is known that gasohol with technical ethanol content below $20 \% \mathrm{v}$ can be used as a fuel substitute for gasoline. Real-time performance test of gasohol in engines has shown that the addition of ethanol content in gasohol tend to increase the engine power at a certain compression ratio, but it also increases fuel consumption because the heat value of ethanol is lower than gasoline. Machine in gasohol with ethanol content below $20 \% \mathrm{v}$ can operate smoothly without having to modify the engine. Based on the studies that have been done, gasohol in the range of $10 \% \mathrm{v}$ ethanol content is well-functioned as a substitute for gasoline fuel and meets fuel specifications required by the General Director of Oil and Gas. The feasibility of using gasohol as an alternative fuel can be studied further.
\end{abstract}

Keywords: gasoline, gasohol, fuel specifications, performance

Article History: Received July, 2014; Received in revised form August 20, 2014; Accepted October 2014; Available online

How to Cite This Article: Murachman, B., Pranantyo, D., \& Putra ,E.S. (2014) Study of Gasohol as Alternative Fuel for Gasoline Substitution: Characteristics and Performances. Int. Journal of Renewable Energy Development, 3(3), 175-183. http://dx.doi.org/10.14710/ijred.3.3.175-183

\section{Introduction}

Fuel crisis faced by the nation recently happens from the reality that the price of crude petroleum in international market becomes very high. Meanwhile, import volume of crude petroleum and fuel keeps increasing. This issue becomes one of the reasons of significant price increase of premium petrol, which will keep increasing until reaching its economic price in the future. This price increase will significantly bring great impact to Indonesian society, considering that Indonesia has high dependence to the use of petroleum fuel and government's subsidy toward national price of petroleum.

*Corresponding author: Tel.: +62-274-566630; fax: +62-274-566630.

E-mail : bmurachman@chemeng.ugm.ac.id (Bardi M.)
Fact shows that production development of alternative fuel in domestic scope, which can substitute at least some small part of petroleum fuel use, cannot be avoided anymore. Biofuel is environmentally friendly fuel promising to reduce the import of petroleum fuel and to increase society welfare. The examples of biofuel that have been developed are biodiesel, bio-oil, biogas, biohydrogen and also bioetanol.

Bioethanol is ethanol $\left(\mathrm{C}_{2} \mathrm{H}_{5} \mathrm{OH}\right)$ that made of a natural source, and it is oxygenate, the name for organic component/oxidized hydrocarbon (Lang-Palmer, 1989). The use of ethanol as fuel material is based on the character of pure ethanol that is flammable and has 
big combustion nett value, which is $21 \mathrm{MJ} /$ liter (about 2/3 from premium combustion heat value). Dry ethanol/absolute/pure (minimum 99.95\%-v alcohol) can completely dissolve with premium in all mixture comparison. It also becomes a high octane mogas component (HOMC) for premium. The rate of mixture octane value is 118 . Because of the character to be able to mix with premium and having high octane value, bioethanol has been used as fuel to mix premium petrol although its application is not widely known. The mixture is famously known as gasohol, the example is Gasohol E10 (mixture 10\% dry bioethanol and 90\% premium). Because of having high octane value, the use gasohol can decrease, even substitute the use of TEL (tetra-ethyl lead) as a component to generate octane premium number which has rate $0.3-0.84 \mathrm{~g} / \mathrm{L}$ premium (Thomas-Kwong, 2001) that pollutes the environment. Environment pollution can be decreased by using gasohol as the fuel because alcohol does not contain sulfur. With affordable price, the use of ethanol in premium petrol will give great benefit for the country, especially in increasing the health of the society. The study about gasohol characteristic and performance as alternative fuel becomes very important to be analyzed in further.

The characteristic of motor fuel which has good performance are as follow:

\section{- Volatilitas}

Fuel volatility has significant influence to starting characteristic in cold condition, vapor lock, carter oil liquid, warming up and acceleration, and economic effort of fuel users in all conditions of the machine. Fuel volatility is determined through the test of Reid vapor pressure (ASTM D 323) and Engler distillation (ASTM D 86) (ASTM, 1985).

Starting Characteristic

Starting characteritic can be known from the value of vapor pressure or Reid Vapour Pressure (RVP) of the fuel. High RVP value of the fuel impacts to the engine which can be started easily in cold condition. The spreading fuel only evaporates a little amount. In order to evaporate the fuel and to form mixture in the air that can be burnt, the air flow need to be reduced with the help of choke. In this condition, the ratio of air/fuel is $1: 1$, whereas normal ratio of air/fuel is $15: 1$ (Hardjono, 2001). To avoid the loss of heavy hydrocarbon compound that cannnot be evaporated in cold condition, additional light hydrocarbon compound is needed in the fuel, generally, it is butan. Butan addition is limited 10\% volume to get fuel with RVP value around 10 psi (Hardjono, 2001).

- Vapour Lock

Vapour lock is the condition in which the fuel stpos flowing both partially and completely because of the formation of vapor in the system of fuel flow. High RVP value of the fuel can cause vapor lock. However, low RVP value of the fuel impacts to the engine that is difficultly started in cold condition. The RVP value of optimum fuel as the compromise between both of the characters, which is around 10 psi (Hardjono, 2001).

\section{- Anti-Knocking}

If the fuel is force to work upon the maximum limit, the fuel will give less force and engine knocking because of premature combustion process.

\section{Carter Oil Dilution}

Carter oil dilution is caused by heavy tip of the fuel. If heavy hydrocarbon compound does not evaporate, there will be small drops that can drop into the carter. The effect is that engine lubrication cannot work as it is expected, so the engine can be worn down. This character can be known from ASTM distillation. Generally, fuel is made in high volatility; it is in $90 \%$ evaporated by ASTM distillation which reaches temperature between $150-175^{\circ} \mathrm{C}$. Therefore, the solution of carter lubrcation oil can only process a little amount. However, the solution of carter lubrication oil can reach more than $5 \%$ volume if the temperature in $90 \%$ evaporated becoming $205^{\circ} \mathrm{C}$ (Hardjono, 2001).

\section{- Warming up and Acceleration}

Warming-up shows a certain period when the engine is started in cold condition and when smooth acceleration can be obtained without using choke. Warming-up characteristic of the fuel depends on the volatility in the middle and the tip part of the fuel. Temperature in 50\% and $90 \%$ evaporated in ASTM distillation shows relative warming-up characteristic of fuel (Hardjono, 2001).

\section{- Effort and Economy}

Fuel volatility has significant influence toward fuel economical and engine effort. The more volatile fuel is, the bigger effort that can be produced. However, it can give an impact to vehicle distance.

There are several important considerations in using ethanol fuel in motor vehicle, as follow(Joseph, 2004):

- Corrosion factor in the metal, it is related to the suitability of fuel to metal material of the vehicle. The test can be done by conducting ASTM 439 test;;

- Chemical reaction factor in plastic/rubber, it is related the suitability of fuel to plastic/rubber material of the vehicle;

- Higher fuel consumption, it is related to the low energy content of fuel molecular;

- The comparison or ratio of the fuel/air for different combustion, is related to less drive-ability of the vehicle;

- Low vapor pressure, it is related to start-up difficulty in cold weather.

Those considerations really depend on three aspects, which are ethanol rate in fuel mixture, ethanol quality and specification, and the age and technology of vehicle that uses ethanol as the fuel.

Special characters of ethanol as fuel (gasohol and neat fuel) are presented in Table 1 . From the table, people 
can analyze several characters of ethanol that influences the quality as fuel; those are combustion heat, vapor pressure, octant number, and corrosive character.

Table 1

Ethanol Characteristics as Motor Vehicle Fuel (Joseph, 2004)

\begin{tabular}{|c|c|c|c|c|}
\hline \multicolumn{2}{|c|}{ Characters } & $\begin{array}{c}\text { Premium } \\
(100 \%)\end{array}$ & $\begin{array}{l}\text { Ethanol } \\
\text { mixture/ } \\
\text { premium } \\
(22 \%-v / v)\end{array}$ & $\begin{array}{l}\text { Ethanol } \\
\text { (hydrate) }\end{array}$ \\
\hline \multicolumn{2}{|c|}{ Stoikiometri fuel/air } & $1: 14,5$ & $1: 12,7$ & $1: 9,0$ \\
\hline \multicolumn{2}{|c|}{ Density $20^{\circ} \mathrm{C}, \mathrm{kg} / \mathrm{m}^{3}$} & \pm 770 & \pm 780 & \pm 810 \\
\hline \multicolumn{2}{|c|}{$\begin{array}{l}\text { Combustion heat, } \\
\mathrm{kcal} / \mathrm{kg}\end{array}$} & \pm 10.500 & \pm 9.600 & \pm 6.100 \\
\hline \multirow{2}{*}{$\begin{array}{l}\text { Octant } \\
\text { number }\end{array}$} & MON & $80 \sim 83$ & $80 \sim 83$ & \multirow[t]{2}{*}{$\begin{array}{l}\text { Octant } \\
\text { number }\end{array}$} \\
\hline & $\begin{array}{l}\text { RON } \\
\text { AON }\end{array}$ & $\begin{array}{c}90 \sim 96 \\
\geq 87\end{array}$ & $\begin{array}{c}90 \sim 96 \\
\geq 87\end{array}$ & \\
\hline \multirow{3}{*}{\multicolumn{2}{|c|}{$\begin{array}{l}\text { Vapor pressure, } \mathrm{kPa} \\
\text { Molecule Polarity } \\
\text { Corrosivity in metal }\end{array}$}} & $55 \sim 70$ & $55 \sim 70$ & Very low \\
\hline & & Low & - & High \\
\hline & & Reference & Quite high & High \\
\hline \multicolumn{2}{|c|}{$\begin{array}{l}\text { Suitability with } \\
\text { plastic material }\end{array}$} & Reference & $\begin{array}{c}\text { Good } \\
\text { (except } \\
\text { with } \\
\text { polyamide) }\end{array}$ & $\begin{array}{c}\text { Good } \\
\text { (except with } \\
\text { polyamide) }\end{array}$ \\
\hline \multirow{2}{*}{\multicolumn{2}{|c|}{$\begin{array}{l}\text { Gum formation } \\
\text { Additional } \\
\text { antioxidant and } \\
\text { detergent }\end{array}$}} & Reference & High & - \\
\hline & & Needed & Not needed & Not needed \\
\hline
\end{tabular}

Other than the previous consideration, there are several things that have to be considered if using ethanol as mixture fuel material. The considerations are as follow:

Adding $10 \%$ v ethanol will increase octane number of fuel approximately 3 point (Scheller-Mohr, 1977). It is similar to Gasohol E10, RON ethanolpremium mixture increases 4 point.

- Octane number increase of the mixture is also influenced by octant number of basis premium. The highest octant number increase in alcohol-premium mixture is by adding ethanol into premium mixture which contains the lowest octant number with the most composition is linear chain component and the result of thermal cracking (Szwarc, 2004).

- Ethanol is a hygroscopic component, so there is tolerant of premium-ethanol mixture before there is separation phase. Gasohol resistance toward water is significantly influenced by system temperature and ethanol concentration. The tendency of phase separation is greater together with temperature loss and alcohol concentration reduction (Bolt, 1980). The test of water tolerance character for fuel is generally done by ASTM D439 test method. In similar alcohol concentration and same temperature, aromatic concentration in premium is linear with mixture resistance to keep forming one phase (Keller, 1984).

- Ethanol has higher evaporation latent heat value than other hydrocarbon compound with the same number of carbon atoms which is $839.31 \mathrm{~J} / \mathrm{g}$ (KirkOthmer, 1981). Evaporation latent heat has important influence in volumetric fuel efficiency until maximum average effective pressure from the motor. Carbureted mixture amount which is poured into the cylinder has reverse ratio with the temperature. If evaporation latent heat of the fuel is low, the temperature will increase and the amount of carbureted mixture which flows to the cylinder is less (Kontawa, 1987).

- The other phenomena that has correlation with mixture volatility is commingling that can happen if fuel containing ethanol is poured in the fuel tank which only contain hydrocarbon fuel initially. The increase of vapor pressure is influenced by two factors; those are the ratio of fuel containing ethanol toward hydrocarbon premium and ethanol concentration in the mixture. The biggest impact that can be analyzed is increased vapor pressure $6,2 \mathrm{kPa}$ in mixture $25 \%$ gasohol (having ethanol concentration $5,7 \%-v$ ) with $75 \%$ premium petrol, although both fuels have similar initial vapor pressure that is $48,3 \mathrm{kPa}$ (Chevron, 2005).

Table 2

Specifications of Gasoline as Required by General Director of Oil and Gas No. 108 K/42/DDJM/1997 (Dated 28th August 1997)

\begin{tabular}{|c|c|c|c|c|}
\hline \multirow[b]{2}{*}{ Characters } & & \multicolumn{2}{|c|}{ Limitation } & \multirow{2}{*}{$\begin{array}{c}\text { Test } \\
\text { Method } \\
\text { (ASTM) }\end{array}$} \\
\hline & & Min. & Max. & \\
\hline $\begin{array}{l}\text { Researched } \\
\text { octane number }\end{array}$ & RON & 88 & & D-2699 \\
\hline $\begin{array}{l}\text { Lead }(\mathrm{Pb}) \\
\text { concentration }\end{array}$ & $\mathrm{gr} / \mathrm{L}$ & & 0,3 & D-3341 \\
\hline \multicolumn{5}{|l|}{ Distillation: } \\
\hline $10 \%-\mathrm{v}$ & ${ }^{\circ} \mathrm{C}$ & & 74 & \\
\hline $50 \%-\mathrm{V}$ & ${ }^{\circ} \mathrm{C}$ & & $125^{*}$ & \\
\hline $90 \%-\mathrm{v}$ & ${ }^{\circ} \mathrm{C}$ & 88 & 180 & \\
\hline FBP/EP & ${ }^{\circ} \mathrm{C}$ & & 205 & \\
\hline Residue & $\% \mathrm{v}$ & & 2 & \\
\hline $\mathrm{RVP}$ in $100^{\circ} \mathrm{F}$ & Psi & & $62^{*}$ & D-323 \\
\hline Residue resin & $\begin{array}{c}\mathrm{mg} / \\
100 \mathrm{~L}\end{array}$ & & 4 & D-381 \\
\hline Induction period & minutes & 240 & & D-525 \\
\hline $\begin{array}{l}\text { Sulphur } \\
\text { concentration }\end{array}$ & $\begin{array}{c}\% \\
\text { mass }\end{array}$ & & 0,2 & D-1266 \\
\hline $\begin{array}{l}\text { Copper corrosion } \\
\left(3 \text { hours } / 122^{\circ} \mathrm{F}\right)\end{array}$ & & & No. 1 & D-130 \\
\hline Doctoral test & & & Negative & IP $30^{* *}$ \\
\hline $\begin{array}{l}\text { Mercaptant } \\
\text { concentration }\end{array}$ & $\begin{array}{c}\% \\
\text { mass }\end{array}$ & & 0,002 & D-3227 \\
\hline Color & & & ow & Visual $^{* *}$ \\
\hline $\begin{array}{l}\text { Coloring } \\
\text { concentration }\end{array}$ & $\begin{array}{c}\text { gr/ } \\
100 \mathrm{~L}\end{array}$ & & 0,13 & \\
\hline Smell & & apl & $\begin{array}{l}\text { ket } \\
\text { riate }\end{array}$ & \\
\hline
\end{tabular}

Table 2 shows the specification of premium fuel. The value that is presented in table 2 is the limit of the characters that become the foundation or characteristic law foundation of premium fuel allowed in Indonesia. 


\section{Research Method}

\subsection{Materials}

The materials used are premium petrol that can be obtained from fuel station, technical ethanol $96 \%$ and aquadest that can be bought in chemical material shop.

\subsection{Procedure}

\subsubsection{Gasohol Characteristic Tests}

$>$ Sample Making

Gasohol sample was made by mixing premium petrol with technical ethanol $96 \%$. Mixture process was conducted in closed glass completed with magnetic stirring. The compositions of the sample are varied with the comparison of technical ethanol volume toward mixture fuel sample $(2 \% \mathrm{v}, 4 \% \mathrm{v}, 6 \% \mathrm{v}, 8 \% \mathrm{v}, 10 \% \mathrm{v}$, $20 \% \mathrm{v}, 30 \% \mathrm{v}, 40 \% \mathrm{v}$ and $50 \%$ ). Mixing process was done in the rotation of $300 \mathrm{rpm}$ during 5 minutes.

$>$ Density Test (Specific Gravity)

The sample was poured in mesured glass completed with thermomether. Measured glass that had been arranged was put inside a waterbath. Waterbath is turned on in the temperature of $60^{\circ} \mathrm{F}\left(15^{\circ} \mathrm{C}\right)$. If the thermometer reached $60^{\circ} \mathrm{F}$, hydrometer was dipped in the sample. Hydrometer scale that was cut by sample surface was noted carefully.

\section{Reid Vapour Pressure (RVP) Test}

Premium petrol room was completely filled by cooled sample. Fuel room with room temperature and manometer was set as it is shown in figure 1. Soaking the equipment series is in constant temperature $100 \pm 0.2^{\circ} \mathrm{F}\left(37.8 \pm 0.1^{\circ} \mathrm{C}\right)$. Periodically the equipment set was set out and pushed until manometer shows constant reid vapor pressure (RVP).

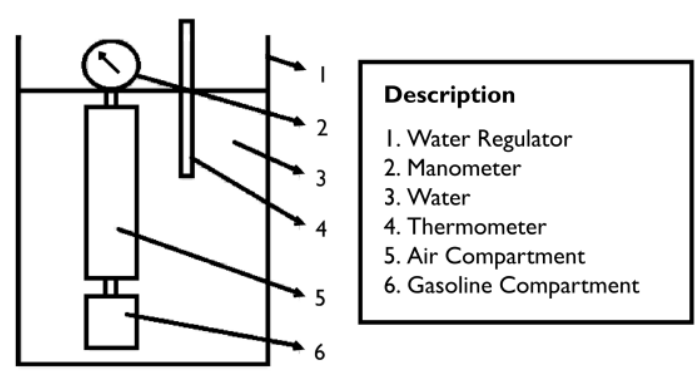

Figure 1. The Series of Reid Vapour Pressure Equipment Test

\section{$>$ Engler Distillation Test}

Electric heater, distillation pot, thermometer, condenser basin and receiver measured glass were arranged as it is shown in figure 2. Distillation pot was fulfilled with $100 \mathrm{~mL}$ sample, and it was closed tightly by using lock rubber. The next, condencer basin was filled with cooling water (ice water). The next step was that turning on electric heater and starting to measure the result. The measurement covers several aspects as follow:

- Initial boiling point/IBP, is the temperature in which the distilate drops at the first time from the tip of condencer pipe.

- The temperature in several distillation presentage are $5,10,20,30,40,50,60,70,80,90$, and $95 \%$ distillation.

- Final boiling point/FBP, is the highest temperature that can be reached during distillation process. Generally it happens after the evaporation of all liquid from the tube.

- Percent (\%) recovery, is the presentage of distillate volume that has been stored in receiver measured glass.

- Percent (\%) residue, is the percentage of residue volume that is left in distillation tube.

- Percent (\%) total recovery, is the amount of result percentage and residue percentage.

- Percent (\%) loss, is $100 \%$ minus percent (\%) total recovery.

- Percent (\%) evaporated, is the calculation amount of recovery percentage and loss percentage.

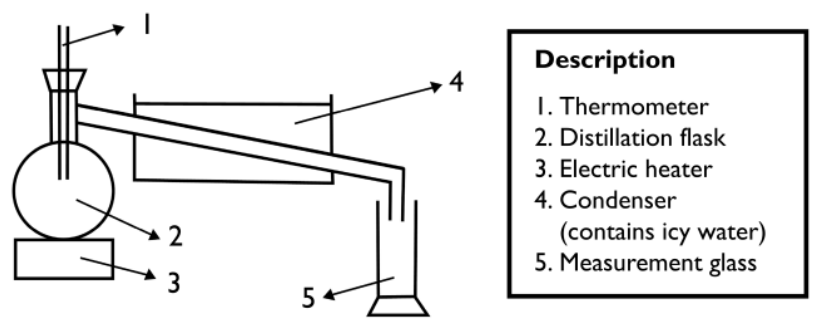

Figure 2. The Series of Engler Distillation Equipment Test (ASTM Distillation)

\section{$>$ Copper Strip Corrosion Test}

Clean the rust of copper plat. Put the sample to test tube. Put the copper plat to test tube until sample is completely dipped. Put test tube to test bomb. Put test bomb to water bath in $100^{\circ} \mathrm{F}$ temperature during 2 hours. Compare copper plat of the test result with ASTM standard colour.

\section{$>$ Terner Diagram Making}

Technical ethanol solution and premium petrol is analyzed by using Gas Chromatography. The next, the sample of premium-ethanol-water in several volume variations is formed by adding technical ethanol solution and aquadest little by little into the premium until forming two shapes. Heavy phase (in top part) and light phase (in bottom part) of premium-ethanol-water mixture was taken and analyzed by using Gas Chromatography.

\subsubsection{Gasohol Performance Test}

Performance test is determined by using two methods: 
Testing in milling machine

The first method was by comparing time or operation duration of milling machine which used 200 $\mathrm{mL}$ gasohol fuel with variation of technical ethanol concentration. In this method, rotation speed (rpm) of the milling machine is also analyzed by using the help of tachometer.

Specifications of milling machine used:

Model series : 133400

Bore : 2-9/16 in (65,09 mm)

Stroke : 2-7/16 in $(61,91 \mathrm{~mm})$

Displacement : 12,57 cube in (206 cc)

Torque : 7,66 ft.lbf/s @ 3000 rpm

$(10,39 \mathrm{~W})$

\section{$>$ Road Test}

The second method is road test; it is to compare the destination of the vehicle which uses one litre gasohol as the fuel with various technical ethanol concentrations. The vehicle used was 2 tak Yamaha Alfa motorcycle.

\section{Result and Discussion}

This reserach focuses on conducting tests toward gasohol characteristics and performance in various ethanol concentration in order to analyze the probability of gasohol as alternative gasoline substitution. Various characteristic parameters that had been obtained in test result of Gasohol in several variations $\%$ volume ethanol are shown in the discussion below:

\section{$>$ Specific Gravity}

The data of measurement and calculation result of gasohol specific gravity is presented in Figure 3. From the calculation, an equation that connects technical ethanol concentration and gasohol specific gravity can be obtained, which is:

$$
Y=0,0006 X+0,7360
$$

where:

- $\mathrm{Y}$ is specific gravity $\left(60^{\circ} \mathrm{F} / 60^{\circ} \mathrm{F}\right)$

- $\mathrm{X}$ is technical ethanol concentration

Average relative fault from this approach was $0.1008 \%$. from figure 3 , it can be seen that adding ethanol can improve fuel specific gravity. Practically, gasohol specific gravity has linear ratio with ethanol concentration in the mixture. That result is quite common because technical ethanol specific gravity was bigger than premium petrol.

From the data of RVP gasohol measurement in figure 4, it can be seen that gasohol with \%v ethanol until $20 \% \mathrm{v}$ has bigger RVP than RVP of regular premium petrol (RVP conventional premium $7.7 \mathrm{psi}$ ). The increase of RVP from gasohol is caused by the existence of volatile ethanol, so the amount of vapor phase increases.

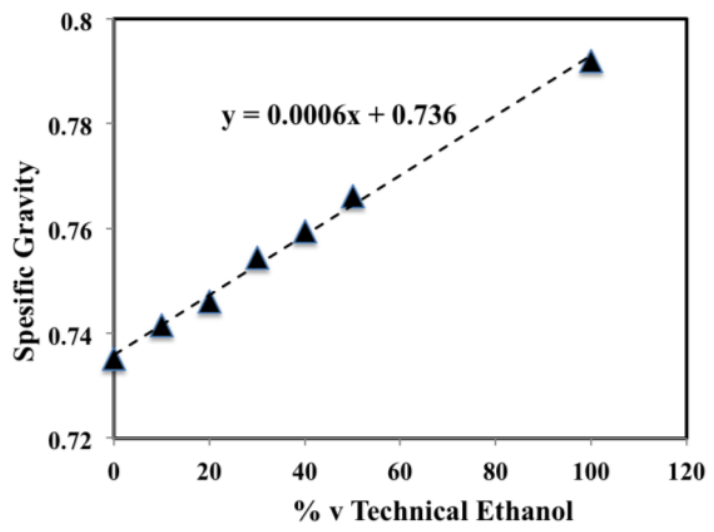

Figure 3. Gasohol Specific Gravity in Several Technical Ethanol Concentrations

\section{$>$ Reid Vapor Pressure (RVP)}

The value of Reid Vapor Pressure has benefit to determine gasohol volatility. The data of Reid Vapor Pressure (RVP) of Gasohol sample is presented in Figure 4.

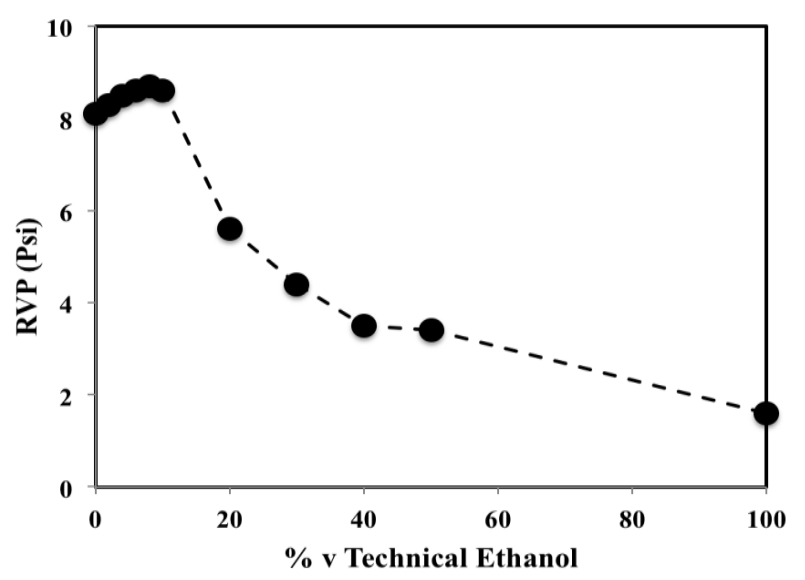

Figure 4. RVP Gasohol Value in Several Technical Ethanol Content

The increase of RVP value does not extend this fuel, in which RVP value does not extend maximum specification of petrol fuel especially premium that is allowed by General Director of Oil and Gas, which is 9 psi. It is expected to work well because it will make the process of machine start in cold condition (cold start). The figure of clearer RVP value to gasohol with \%v ethanol until 20\% can be seen in Figure 5.

Figure 4 and 5 show that the tendency of RVP decrease has started to be obvious when ethanol concentration is above $8 \% \mathrm{v}$ in which \%volume above $20 \%$, measured RVP gasohol decreases lower than regular premium. Decrease of RVP value happens because of the amount of water in gasohol by the increase of the volume of technical ethanol mixture, and it causes gasohol volatility change (water is more difficult to evaporate compared to premium petrol and ethanol). 


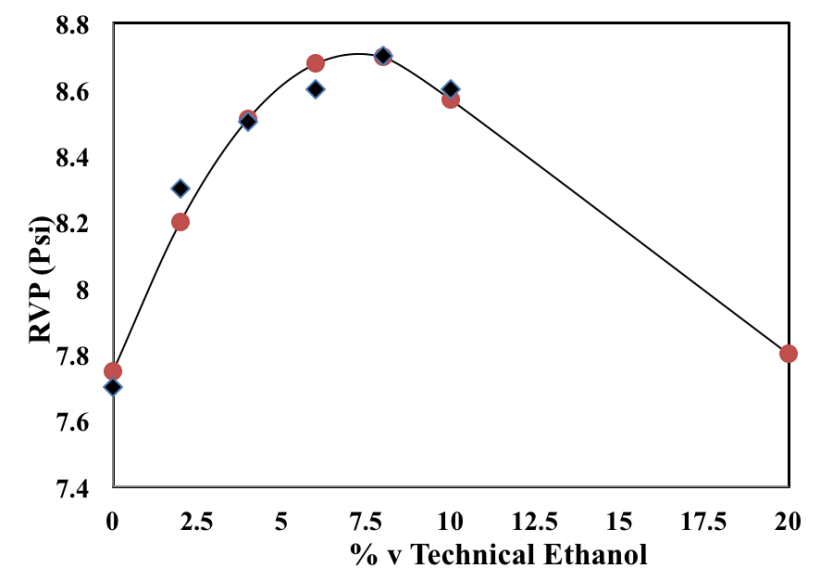

Figure 5. Relation of Ethanol Content and RVP Value in Gasohol

From the calculation result, it can obtain equation of relation between technical ethanol content with RVP value, as follow:

$Y=0,0006 X^{3}-0,0274 X^{2}+0,2959 X+7,7337$

where:

- $\quad \mathrm{Y}$ is RVP value, psi

- $\mathrm{X}$ is technical ethanol content, $\%-\mathrm{V}$

Maximum reverse point is in $7.0169 \% \mathrm{v}$ technical ethanol with maximum RVP value 8.6682 psi.
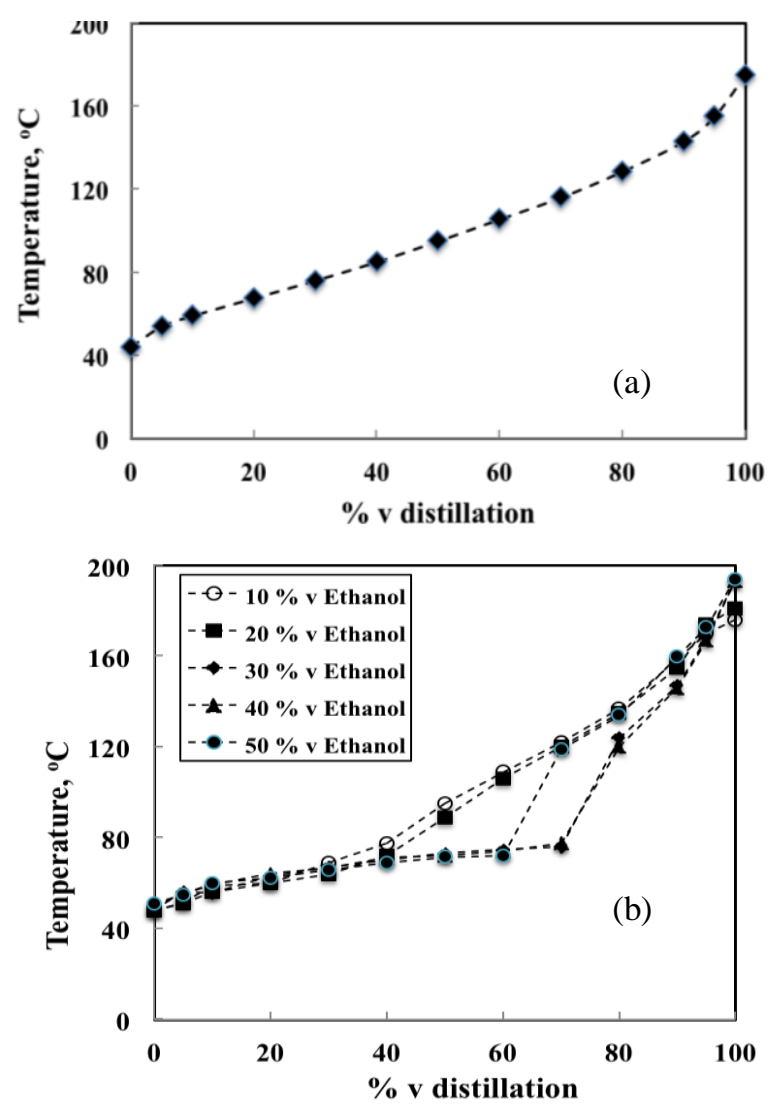

Figure 6. Engler Distillation Curve from (a) Premium Petrol and (b) Gasohol

\section{$>$ Result of Engler Distillation}

Engler distillation is obtained to foresee the performance of gasohol use as fuel. The result data of calculation and measurement of Engler distillation based on ASTM for premium petrol and gasohol sample is shown in Figure 6.

By comparing the Figures 6(a) and (b), it can be seen that adding technical ethanol plays significant role to fuel performance. For light fraction, adding technical ethanol does not influence the change of distillation temperature. However, adding technical ethanol gives significant temperature change toward middle fraction.

Figure 6(b) shows that with Engler distillation curve gasohol from the concentration \%v, ethanol $10 \%$ and 20\% were close to Engler distillation curve result from premium petrol, while adding technical ethanol $30 \% \mathrm{v}$ above there has been temperature drop 40 until $90 \% \mathrm{v}$ distillation. Distillation temperature drop happens because ethanol and water are pure components with constant boiling temperature, which are $78^{\circ} \mathrm{C}$ and $100^{\circ} \mathrm{C}$. It is different from petrol that becomes the product of petroleum. Premium petrol consists of light components until heavy components, so the boiling point is varied forming boiling temperature range.

Distillation temperature drop phenomena indicates that there is much light fraction which exists in middle fraction, so it can cause vapor lock. Even starting from technical ethanol $30 \% \mathrm{v}$ requirement of minimum temperature $88^{\circ} \mathrm{C}$ for $50 \% \mathrm{v}$ distillation could not reach the objective, as it is stated by Oil and Gas General Director. This can cause the icing process in the carburettor of motorized vehicle, other than vapor lock. Good indication can be seen in temperature $90 \% \mathrm{v}$ evaporated that did not exceed $175^{\circ} \mathrm{C}$. It means that adding technical ethanol until $50 \%-\mathrm{v}$, there was only oil liquid of carter lubricant.

\section{$>$ Corrosivity}

From the result of copper strip corrosion test, it can be obtained taht all samples, including pure premium petrol or gasohol with technical ethanol concentration $10,20,30,40$, and $50 \%-\mathrm{v}$, gives corrosion rate $1 \mathrm{~A}$. It indicates that the use of little gasohol will cause corrosion in motor vehicle.

\section{$>$ Terner Diagram System of Ethanol-Gasoline-Water}

The analysis of gas chromatography has given data of three components composisition (Premium, , ethanol and water) either in light or heavy phase. Balance curve liquid-liquid system ethanol-premium-water in Terner diagram is presented in Figure 7.

Separation phase was started by the existence of smoke or fog in the mixture. When water concentration in the system increases, there is hydrogen bond with water molecules and alcohol molecules that can separate the mixture. 


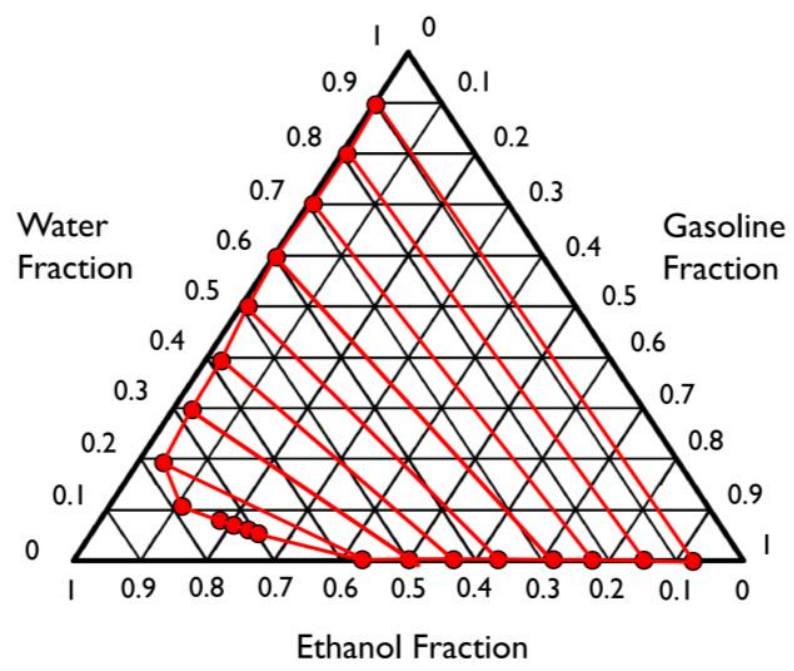

Figure 7. Terner Diagram Premium-Ethanol-Water in Room Temperature

Light phase is dominated by hydrocarbon paraffin components (n-hexane, cyclo-hexane, etc), while heavy phase consists of alcohol, water, and little amount of aromatic hydrocarbon. This phase separation is not expected in gasohol use as fuel because it can cause icing process in fuel pipe line and difficulty in engine start up.

Based on the result of gasohol characteristic test that has been obtained, it can be concluded that gasohol with technical ethanol concentration under $20 \% \mathrm{v}$ (exactly amount of \%vol) can fulfil the specification to substitute premium petrol fuel. In further, gasohol samples need to be tested directly with real machine to make sure the performance when it is operated.

\section{The Analysis of Gasohol Performance}

The analisys of gasohol performance is tested to two kinds of machines with different fuel. Those are milling machine and 2 tak motorcycle. The data result for the sample of gasohol performance and premium petrol in milling machine can be seen in Figure 8(a) and (b), while the data result of gasohol performance sample in Yamaha Alfa 2 tak motorcycle can be seen in Figure 9.

Based on the test of operation duration of milling machine with sample fuel $200 \mathrm{ml}$ (Figure 8(a)), it can be obtained data that the duration of machine rotation increases together with the increase of technical ethanol content until reaching a particular point. After that, adding technical ethanol causes dropped machine rotation. The increase of machine rotation time until a particular ethanol concentration is caused by increase volume of fuel because of adding technical ethanol.

According to the literature, adding $10 \% \mathrm{v}$ dry ethanol can cause additional volume around $0.23 \%$, while maximum enfoldment (reaching around $0.55 \%$ ) happens in ethanol concentration $10-20 \% \mathrm{v}$, exactly in 12.5\%-v (Scheller-Mohr, 1977).
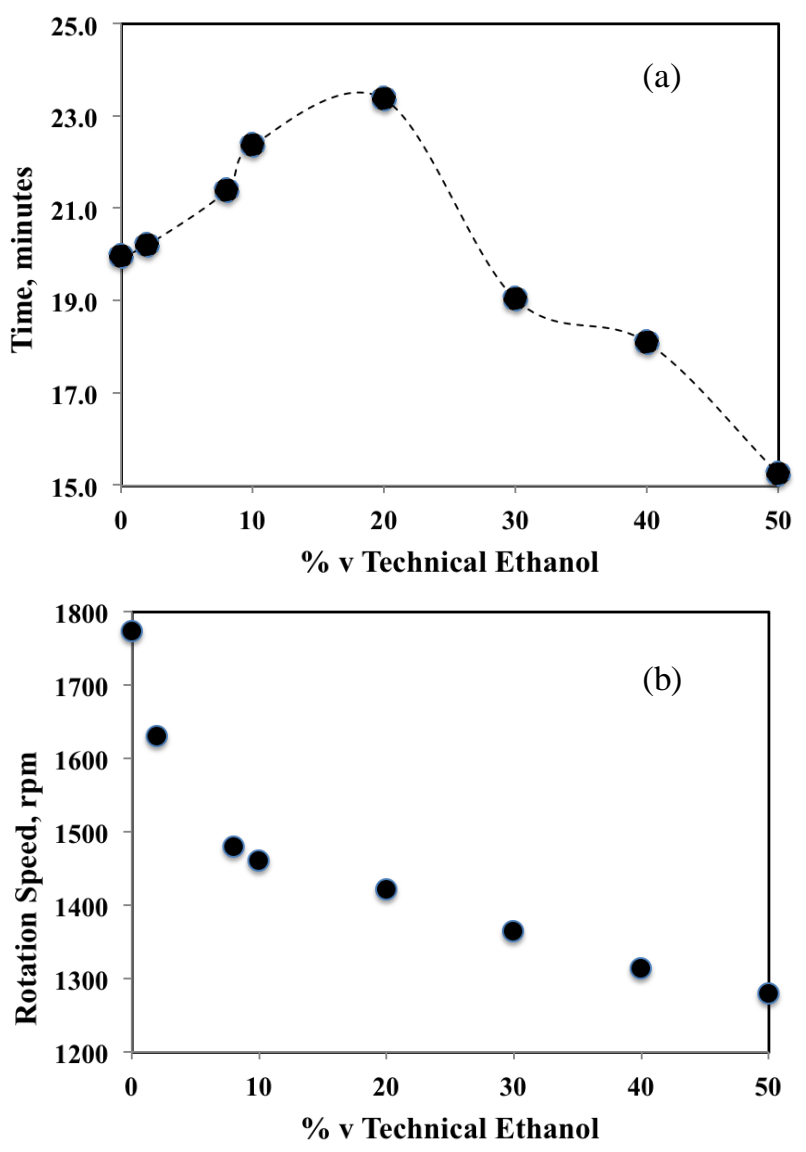

Figure 8. Test result: (a) Operation Duration and (b) Milling Rotation Speed, with Gasohol $200 \mathrm{~mL}$

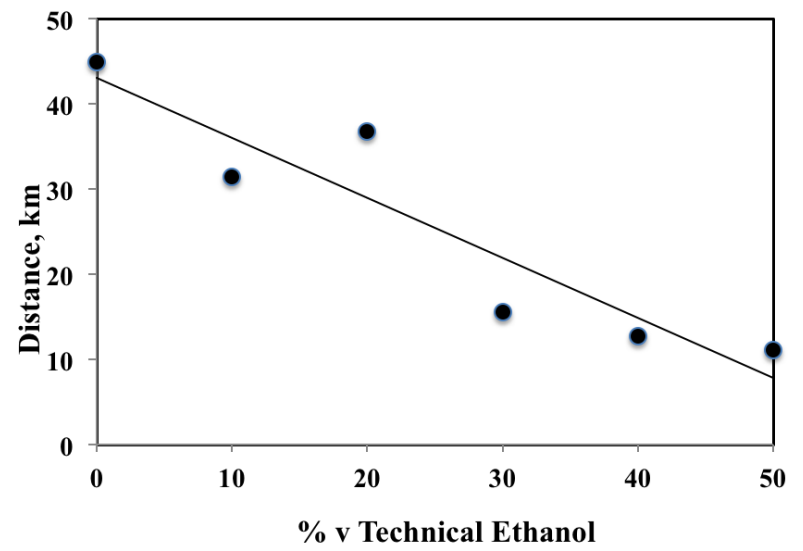

Figure 9. The Distance of Yamaha Motor with 1 Litre Gasohol.

Enfoldment volume of course gives extra fuel supply that can prolong machine operation duration. The speed of machine rotation decreases with adding technical ethanol. Decrease of the speed of machine rotation marks decrease power given from combustion result. This also contributes to the increasing duration of machine operation. With a particular capacity of fuel, smaller power supply gives longer operation duration.

Figure 8(b) shows that until adding 20\%(v/v) technical ethanol, the speed of machine rotation 
decreases that gives an impact to time increase of machine operation. However, technical ethanol content above $20 \% \mathrm{v}$ (for example $30 \% \mathrm{v}$ ), both parameter machine performance, both in operation duration and rotation speed, decreases drastically. It is similar to the result of road test in Figure 9, adding technical ethanol impacts to decreased vehicle distance. This phenomenon is caused by lower heat value of ethanol compared to heat value of hydrocarbon that has been substituted. On the other words, premium petrol which contains oxygenate compound like ethanol has lower heat value. Nett heat value of premium petrol is 30.7 $\mathrm{MJ} / \mathrm{L}$, while ethanol is $21.4 \mathrm{MJ} / \mathrm{L}$ (Meridian Corp., 1991). The use of fuel with different heat value, heat factor of fuel per volume is as important as fuel-air ratio. Energy decreased per volume unit causes to the increase of fuel flow speed, so the machine can be operated well.

Another phenomenon that needs to be concerned is the performance of milling machine and motor which do not run smoothly in technical ethanol content above $20 \% \mathrm{v}$. This happens because there is separation phase in gasohol mixture, shown by the existence of fog in the mixture. Phase separation can trigger various fuel supply to carburettor between premium petrol and ethanol (in turn), whereas net heat value of both compositions is different. In turn fuel supply between high heat to low heat (vice versa) causes machine performance that works in turn between good and bad performance (vice versa), so the machine performance does not work smoothly.

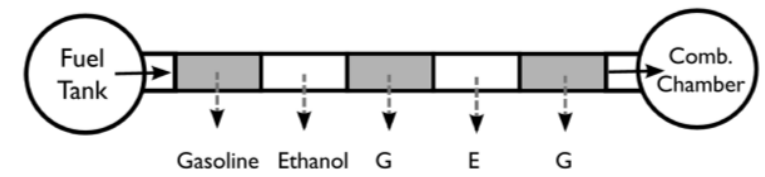

Figure 10. Gasoline and Ethanol in Turn Going to Combustion Room

From the literature above, analysis result which tends to have similarity on gasohol similar character is obtained in the study, as it can be seen in Figure 11-14.

From the graphic data, it can be known that premium petrol produces bigger power and machine torsion than naphtha, a crude oil product that is close with premium fraction. While naphtha mixture with alcohol produces smaller power and machine torsion. It happens because naphtha combustion heat is between premium and alcohol.

The value of air-fuel ratio (AFR) for gasohol is higher than premium and naphtha, and it has lower combustion heat. Therefore, it needs more oxygen for its combustion. This needs to use more often choke to use gasohol in conventional machine (without modification).

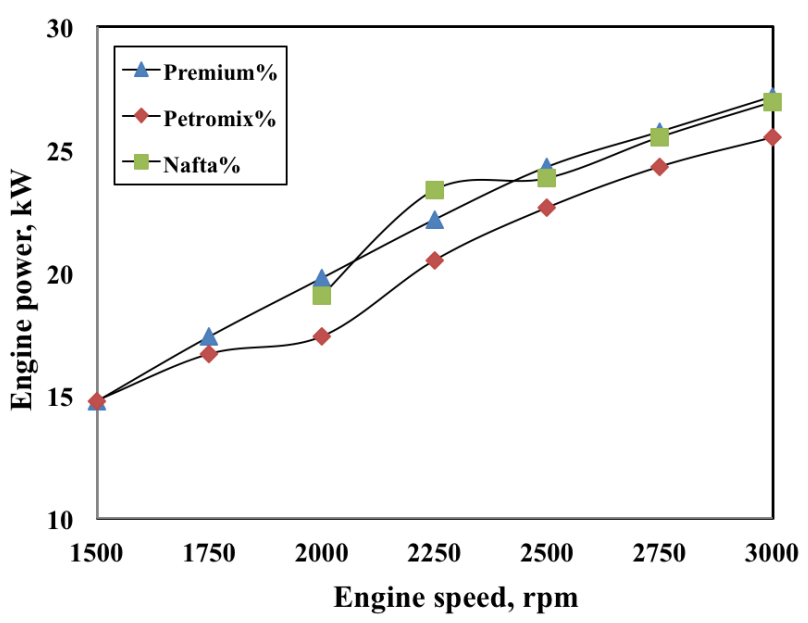

Figure 11. Engine Speed vs Engine Power

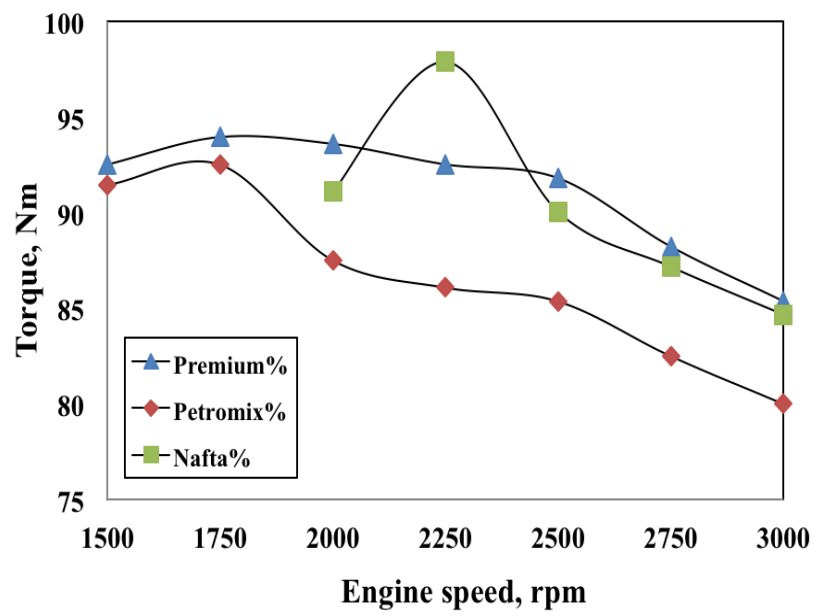

Figure 12. Engine Speed vs Torque

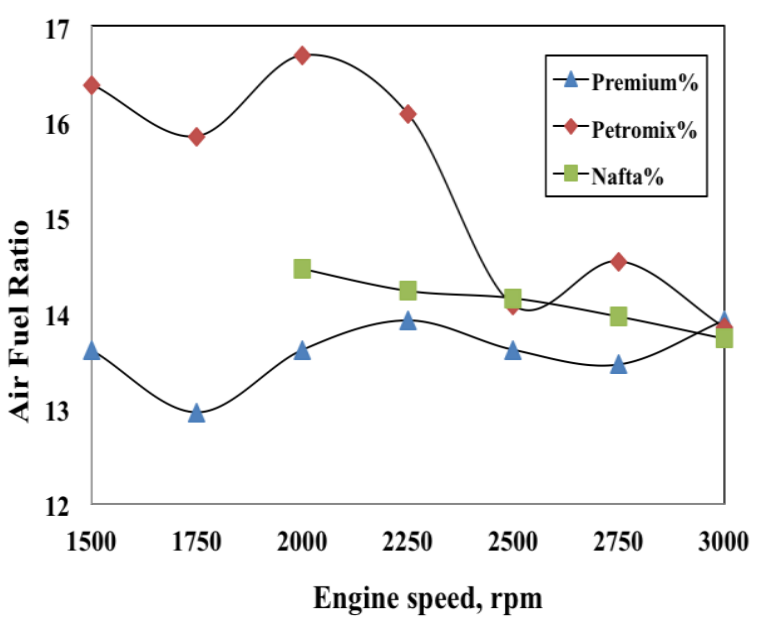

Figure 13. Engine Speed vs Air Fuel Ratio

The value of specific fuel consumption (SFC) and gasohol fuel consumption is higher than premium and naphtha. As it has been explained above, this shows obvious net heat difference between ethanol and premium. 


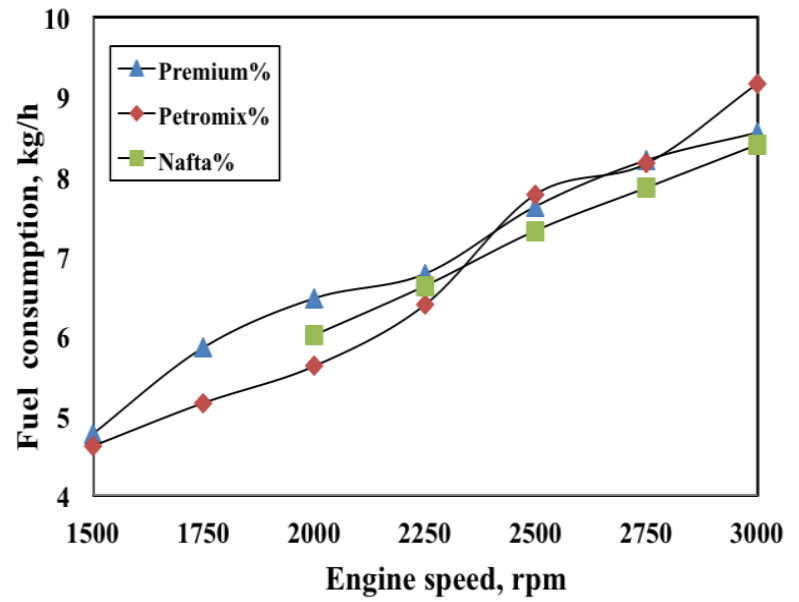

Figure 14. Engine Speed vs Fuel Consumption (Source : Murachman, 2000)

Generally, adding the concentration of ethanol tends to increase the engine power in a particular compression ratio. The greater power causes vehicle maximum speed that can be reached in shorter acceleration time compared to vehicle with premium petrol as its fuel. However, fuel consumption will also increase because of the lower value of ethanol heat than premium petrol.

\section{Conclusion}

The conclusion that can be taken from the study as follow:

- Gasohol specific gravity has linear ratio with ethanol in the fuel.

- Adding technical ethanol until 7.0169\%v increases the value of gasohol vapor pressure in $8.6682 \mathrm{psi}$, and after the value of vapor pressure decrease by adding the amount of ethanol. However, gasohol vapor pressure (RVP) until $20 \%$ v ethanol is still high compared to regular premium petrol. Smaller RVP value than 9 psi is preffererable because it will make cold start easier.

- Technical ethanol content above $30 \% \mathrm{v}$ causes significant temperature decrease started from $40 \% \mathrm{v}$ distilation above. This can cause vapor lock and icing in carburator.

- Gasohol corosivity with 50\%v techical ethanol content is same as premium petrol, which has corotion rate $1 \mathrm{~A}$.

- The higher ethanol concentration used in gasohol (the less water amout in gasohol), the lower tendency of phase separation. Phase separation causes icing in fuel pipe and difficulty in engine start up.

- Adding ethanol concentration tends to increase the engine power in a particular compression ratio, but fuel consumption also increases because ethanol calor value is lower than premium petrol.
- Gasohol with ethanol content until 20\%(v/v) can be used by vehicle engine smoothly. The use of gasohol with ethanol content above $20 \%$ v needs to have engine modification, especially material use for fuel setting system and calibration system.

- Based on the study that has been done, gasohol with the $10 \%(\mathrm{v} / \mathrm{v})$ technical ethanol content can work well as premium petrol substitution which is required by General Director of Oil and Gas. The feasibility of using gasohol as an alternative fuel can be studied further.

\section{References}

ASTM, (1985), ASTM Standard on Petroleum Products and Lubricants, pp. 19-177, The American Society for Testing Materials, Philadelphia.

Bolt, J.A., (1980), A Survey of Alcohol as a Motor Fuel, SAE PT-80/19.

Hardjono, A., (2001), Teknologi Minyak Bumi, edisi pertama, pp. 3945, 63-76, Gadjah Mada University Press, Yogyakarta (In: Bahasa Indonesia).

Joseph Jr., H., (2004), Ethanol Application as Vehicular Fuel in Brazil, The Conference on Biofuel: Challenges for Asian Future, Bangkok, 30-31 Aug 2004.

Keller, J.L., (1984), Ethanol and Methanol as Fuel, Encyclopedia of Chemical Processing and Design, vol. 20, J. McKetta and W. Cunningham, pp. 11-39, Marcel Dekker, New York.

Kirk and Othmer, (1981), Encyclopedia of Chemical Technology, vol. 8, 3 ed., John Wiley and Sons, Inc., New York.

Kontawa, A., (1987). Minyak Bumi - Pengklasifikasian dan Evaluasi, Bahan Ceramah dan Kursus-kursus, Pusat Pengembangan Teknologi Minyak dan Gas Bumi LEMIGAS, Jakarta.

Lang, G.J. and Palmer, F.H., (1989), Gasoline And Diesel Fuel Additives: The Use of Oxygenates in Motor Gasolines, Critical Reports on Applied Chemistry, vol. 25, K. Owen ed., pp. 133-169, John Wiley \& Sons, New York.

Meridian Corporation (Fuel and Transportation Division), (1991), Properties of Alcohol Transportation Fuels - Alcohol Fuels Reference Work \#1, Biofuels System Division, Office of Alternative Fuels, U.S. D.O.E., Jul 1991.

Murachman, B., (2000), Pemanfaatan Alkohol sebagai Campuran Bahan Bakar Fraksi Bensin, Laboratorium Teknologi minyak bumi, Jurusan Teknik Kimia Universitas Gadjah Mada, Yogyakarta (In: Bahasa Indonesia).

Scheller, W.A. and Mohr, B.J., (1977), Gasoline Does, Too, Mix with Alcohol, Chemtech, Oct 1977, pp. 616-623.

Szwarc, A., (2004), Fuel Ethanol Production and Use: A Technical Overview, The Conference on Biofuel: Challenges for Asian Future, Bangkok, 30-31 Aug 2004.

Thomas, V. and Kwong, A., (2001). Ethanol as a Lead Replacement: Phasing Out Leaded Gasoline in Africa, Energy Policy 2001, 29, pp. 1133-1143.

http://www.chevron.com/products/prodserv/fuels/bulletin/motorg as/downloads/Motor_Fuels_Tch_Rvw_chp4.pdf 